\title{
Salinicoccus kunmingensis sp. nov., a moderately halophilic bacterium isolated from a salt mine in Yunnan, south-west China
}

Correspondence
Xiao-Long Cui
xlcui@ynu.edu.cn
or
xlcuiynu@yahoo.com.cn

Various kinds of moderately/extremely halophilic bacteria and archaea have been isolated from ancient salt deposits, in which several new taxa were identified (Dombrowski, 1966; Grant et al., 1998; Norton \& Grant, 1988; Norton et al., 1993; Vreeland \& Powers, 1999; Vreeland et al., 2000; McGenity et al., 2000). In a recent study of the microbial diversity of the ancient salt deposit of the Yipinglang salt mine $\left(25^{\circ} 18^{\prime} \mathrm{N} 101^{\circ} 54^{\prime} \mathrm{E}\right)$ in Yunnan, south-west China, a moderately halophilic, facultatively alkaliphilic strain, YIM Y $15^{\mathrm{T}}$, was isolated from a brine sample. Polyphasic taxonomic study of the phenotypic, chemotaxonomic and genotypic characteristics and phylogenetic position of strain YIM $\mathrm{Y}^{\mathrm{T}}{ }^{\mathrm{T}}$ indicated that this strain represented a novel species of the genus Salinicoccus.

The GenBank/EMBL/DDBJ accession number for the 16S rRNA gene sequence of strain $\mathrm{YIM} Y 15^{\top}$ is DQ837380.
Brine, saline soil and halite samples were collected from the Yipinglang salt mine at a depth of about $200 \mathrm{~m}$. Serial dilutions $(1: 10)$ of the samples were plated on Difco marine agar 2216 (MA; pH 7.2) supplemented with 0$20 \%(\mathrm{w} / \mathrm{v}) \mathrm{NaCl}$ and ISP medium 2 agar (Shirling \& Gottlieb, 1966) at $28{ }^{\circ} \mathrm{C}$ for 7-28 days. A yellow-pigmented colony, named strain YIM Y15 ${ }^{\mathrm{T}}$, was picked from a brine plate of MA. Unless otherwise indicated, morphological and physiological studies were performed with cells grown on MA supplemented with $8 \%(\mathrm{w} / \mathrm{v}) \mathrm{NaCl}$ at $\mathrm{pH} 8.0$ and $37{ }^{\circ} \mathrm{C}$ and on some other media as controls, e.g. nutrient agar, tryptic soy agar (TSA; BBL) and ISP medium 2 agar. The strain was maintained both on agar slants of MA supplemented with $8 \%(\mathrm{w} / \mathrm{v}) \mathrm{NaCl}(\mathrm{pH} 8.0)$ at $4{ }^{\circ} \mathrm{C}$ and in Difco marine broth (MB) supplemented with $20 \%(\mathrm{v} / \mathrm{v})$ glycerol at $-80{ }^{\circ} \mathrm{C}$.

Cell morphology was examined by light microscopy (model BH 2; Olympus). Gram staining was carried out 
using the standard Gram reaction combined with the $\mathrm{KOH}$ lysis test method (Gregersen, 1978). Anaerobic growth was determined using the GasPak Anaerobic System (BBL) according to the manufacturer's instructions. Motility was observed on half-strength MA, solidified with $0.3 \%$ agar, under high-moisture conditions and in a hanging-drop preparation under a $\times 100$ objective lens with oil immersion.

Cells of strain YIM Y15 ${ }^{\mathrm{T}}$ were Gram-positive cocci, approximately $0.8-1.2 \mu \mathrm{m}$ in diameter, occurring singly and in pairs, tetrads or clumps, and strictly aerobic, nonmotile and non-sporulating. Colonies were circular, convex, yellow-pigmented and non-translucent with shiny, glistening surfaces and entire margins, $2-3 \mathrm{~mm}$ in diameter after incubation for 3 days at $37^{\circ} \mathrm{C}$ on MA supplemented with $8 \%(\mathrm{w} / \mathrm{v}) \mathrm{NaCl}$. No diffusible pigments were produced on any media tested.

Genomic DNA extraction, PCR-mediated amplification of the 16S rRNA gene and purification of PCR products were carried out as described by Cui et al. (2001). Electrophoresis of sequencing reaction products was done by using a Beckman CEQ 2000 sequencer according to the manufacturer's protocol. The resulting 16S rRNA gene sequence was compared to sequences obtained from the GenBank database to find the most closely related species. Phylogenetic analyses were performed using the software package MEGA version 2.1 (Kumar et al., 2001) after multiple alignment of sequence data by CLUSTAL_X (Thompson et al., 1997). Distances (corrected by Kimura's two-parameter model; Kimura, 1980) were calculated and clustering was performed with the neighbour-joining method (Saitou \& Nei, 1987). Maximumlikelihood (Felsenstein, 1981) and parsimony (Kluge \& Farris, 1969) trees (not shown) were generated using treeing algorithms contained in the PHYLIP package (Felsenstein, 1993). Bootstrap analysis was used to evaluate the tree topology of the neighbour-joining data by means of 1000 resamplings (Felsenstein, 1985).

The almost-complete 16S rRNA gene sequence (1493 bp) of strain YIM Y $15^{\mathrm{T}}$ was determined. A neighbour-joining tree (Fig. 1) showed that strain YIM Y15 ${ }^{\mathrm{T}}$ was closely related to the type strains of the five recognized members of the genus Salinicoccus Ventosa et al. 1990, and the six strains formed a distinct clade in the phylogenetic tree with significant bootstrap support ( $99 \%$ ), in which strain YIM $\mathrm{Y}^{\mathrm{T}}$ and Salinicoccus alkaliphilus JCM $11311^{\mathrm{T}}$ (Zhang et al., 2002) formed a distinct subclade (Fig. 1). The values of 16S rRNA gene sequence similarity between strain YIM $\mathrm{Y}^{15^{\mathrm{T}}}$ and the five closest relatives were $96.0 \%$ ( $S$. alkaliphilus JCM $11311^{\mathrm{T}}$ ), $94.9 \%$ (Salinicoccus roseus DSM 5351 ${ }^{\mathrm{T}}$; Ventosa et al., 1990), 94.8\% [Salinicoccus jeotgali KCTC $13030^{\mathrm{T}}$ (Aslam et al., 2007); Salinicoccus salsiraiae LMG $22840^{\mathrm{T}}$ (França et al., 2006)] and $94.7 \%$ (Salinicoccus hispanicus DSM 5352 ${ }^{\mathrm{T}}$; Marquez et al., 1990; Ventosa et al., 1992). It has been suggested that bacterial strains with less than $97 \%$ 16S rRNA gene sequence

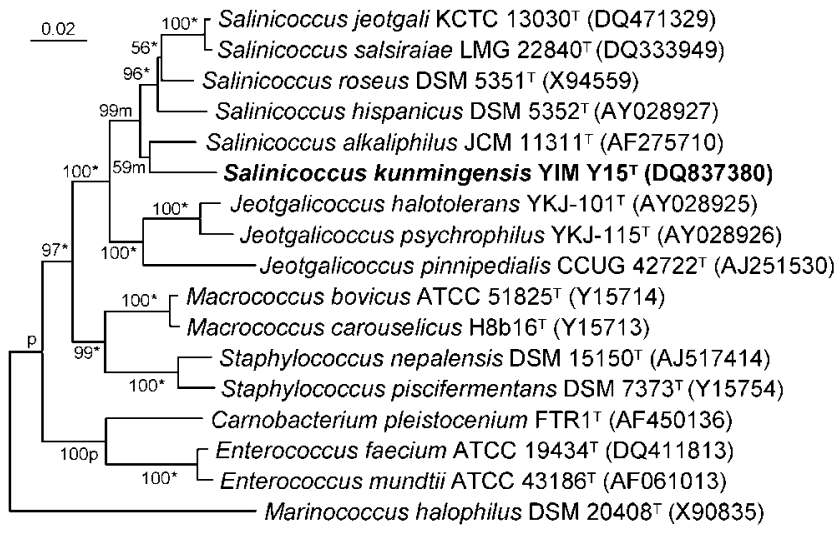

Fig. 1. Phylogenetic dendrogram based on 16S rRNA gene sequences and constructed using the neighbour-joining method showing the phylogenetic positions of strains $\mathrm{YIM} Y 15^{\top}$ and related taxa. Labels ' $m$ ' and ' $p$ ' indicate branches that were also found with the maximum-likelihood (Felsenstein, 1981) or parsimony (Kluge \& Farris, 1969) algorithms; asterisks indicate branches that were recovered with all three methods. Numbers at nodes indicate bootstrap values $(>50 \%)$ based on neighbourjoining analyses of 1000 resampled datasets. Bar, 2 substitutions per 100 nucleotides.

identity are members of different genomic species (Stackebrandt \& Goebel, 1994). It is therefore evident from the phylogenetic data that strain YIM Y $15^{\mathrm{T}}$ represents a previously unknown species of the genus Salinicoccus.

Growth was tested at different temperatures $(4,10,15,20$, $25,30,37,45$ and $50{ }^{\circ} \mathrm{C}$ ) on MA supplemented with $8 \%$ $(\mathrm{w} / \mathrm{v}) \mathrm{NaCl}$ and at different $\mathrm{pH}$ values $(5.0,6.0,7.0,8.0$, 9.0, 10.0 and 11.0) in $\mathrm{MB}$ supplemented with $8 \%(\mathrm{w} / \mathrm{v})$ $\mathrm{NaCl}$. For $\mathrm{pH}$ tolerance experiments, the following buffer solutions were used: $\mathrm{pH} \mathrm{5.0,} \mathrm{citric} \mathrm{acid/sodium} \mathrm{citrate;}$ $\mathrm{pH}$ 6.0, 7.0, 8.0, $\mathrm{NaOH} / \mathrm{KH}_{2} \mathrm{PO}_{4} ; \quad \mathrm{pH} 9.0, \quad 10.0$, $\mathrm{Na}_{2} \mathrm{CO}_{3} \cdot 10 \mathrm{H}_{2} \mathrm{O} / \mathrm{NaHCO}_{3} ; \mathrm{pH} 11.0, \mathrm{Na}_{2} \mathrm{HPO}_{4} \cdot 10 \mathrm{H}_{2} \mathrm{O} /$ $\mathrm{NaOH}$. Tolerance of/requirement for salts was determined on MA containing $0-30 \%(\mathrm{w} / \mathrm{v}) \mathrm{NaCl}, \mathrm{MgCl}_{2}$ or $\mathrm{KCl}$. For the catalase test, the evolution of bubbles upon addition of $3 \% \mathrm{H}_{2} \mathrm{O}_{2}$ solution to cells was observed under a stereoscopic microscope. Oxidase activity was tested by the oxidation of $1 \%(\mathrm{w} / \mathrm{v})$ tetramethyl- $\beta$-phenylenediamine (bioMérieux). Hydrolysis of polymers, urease activity, nitrate reduction and Voges-Proskauer and methyl red tests were determined as described previously (Cowan \& Steel, 1965; Gerhardt et al., 1981; Ventosa et al., 1982). Substrate utilization as sole carbon and energy sources, the fermentation/oxidation profile, acid production, activities of constitutive enzymes and some other physiological characteristics were examined using API 20E, API 20NE, API $50 \mathrm{CH}$ (with API $50 \mathrm{CH}$ B/E medium) and API ZYM strips (bioMérieux) according to the manufacturer's instructions. Additionally, Biolog GP2 MicroPlates and the MicroLog computer software (Biolog) were used. All suspension media were supplemented with $2 \%(\mathrm{w} / \mathrm{v})$ 
$\mathrm{NaCl}$. Antibiotic resistance was determined by inoculating bacterial suspension on $\mathrm{MA}$ at $37^{\circ} \mathrm{C}$ and applying Antibiotics-Sensitabs (Tiantan Medicine Co.). Inhibition zones were measured after 5 days incubation and interpreted according to the manufacturer's manual.

Strain YIM Y $15^{\mathrm{T}}$ was catalase- and oxidase-positive, with a wide growth temperature range of $4-45{ }^{\circ} \mathrm{C}$ (optimum $37^{\circ} \mathrm{C}$ ). It was moderately halophilic, as the optimum $\mathrm{NaCl}$ concentration for growth was between 8 and $10 \%$, with a $\mathrm{NaCl}$ concentration range for growth of $0.5-25 \%(\mathrm{w} / \mathrm{v})$ (Kushner, 1993). Good growth occurred on MA (containing $19.5 \mathrm{~g} \mathrm{NaCl}^{-1}$ ) and TSA (containing $5.0 \mathrm{~g} \mathrm{NaCl} \mathrm{l}^{-1}$ ), but there was no growth on nutrient agar or ISP 2. Strain YIM $\mathrm{Y}^{\mathrm{T}} 5^{\mathrm{T}}$ was a facultatively alkaliphilic organism with a growth range of $\mathrm{pH} 6.0-10.0$, and optimum growth was observed at $\mathrm{pH}$ 8.0. The results of other phenotypic tests are listed in the species description and in Table 1.

Isolation of the cell-wall fraction and preparation of the hydrolysate of the cell wall were carried out using the method of Schleifer (1985). The amino acid composition of the cell-wall hydrolysate was determined by using TLC as described by Staneck \& Roberts (1974). Isoprenoid quinones were analysed by HPLC as described by Groth et al. (1996). For isoprenoid quinone analyses, the organism was inoculated in $\mathrm{MB}$ supplemented with $8 \%$ $(\mathrm{w} / \mathrm{v}) \mathrm{NaCl}$ in flasks on a rotary shaker at 200 r.p.m. The biomass was harvested by centrifugation, washed twice with distilled water and freeze-dried. The fatty acid

Table 1. Differentiating characteristics of strain $\mathrm{YIM} \mathrm{Y} 15^{\top}$ from its closest phylogenetic relatives

Strains: 1, YIM Y15 ${ }^{\mathrm{T}}$ (data from this study); 2, S. alkaliphilus JCM 11311 ${ }^{\mathrm{T}}$ (Zhang et al., 2002); 3, S. roseus DSM 5351 ${ }^{\mathrm{T}}$ (Ventosa et al., 1990); 4, S. hispanicus DSM 5352 ${ }^{\mathrm{T}}$ (Marquez et al., 1990; Ventosa et al., 1992); 5, S. jeotgali KCTC 13030 ${ }^{\mathrm{T}}$ (Aslam et al., 2007); 6, S. salsiraiae LMG 22840 ${ }^{\mathrm{T}}$ (França et al., 2006). +, Positive; -, negative; ND, no data.

\begin{tabular}{|c|c|c|c|c|c|c|}
\hline Characteristic & 1 & 2 & 3 & 4 & 5 & 6 \\
\hline Colony pigmentation & Yellow & Pinkish & Pink-red & Reddish orange & Orange & Pink-red \\
\hline \multicolumn{7}{|l|}{ Temperature for growth $\left({ }^{\circ} \mathrm{C}\right)$} \\
\hline Optimum & 37 & 32 & 37 & 37 & 30 & 37 \\
\hline \multicolumn{7}{|l|}{$\mathrm{NaCl}$ for growth $(\% ; \mathrm{w} / \mathrm{v})$} \\
\hline Range & $0.5-25.0$ & $0-25.0$ & $0.5-25.0$ & $0.9-25.0$ & $0.5-15$ & $0-22$ \\
\hline \multicolumn{7}{|l|}{$\mathrm{pH}$ for growth } \\
\hline Range & $6.0-10.0$ & $6.5-11.5$ & $5.0-9.0$ & $6.0-9.0$ & $6.5-11.0$ & $6.5-9.5$ \\
\hline Optimum & 8.0 & 9.5 & 7.5 & 8.0 & 7.0 & 8.0 \\
\hline \multicolumn{7}{|l|}{ Hydrolysis of: ${ }^{*}$} \\
\hline Aesculin & + & $-\dagger$ & - & + & ND & - \\
\hline Casein & - & - & + & - & - & + \\
\hline Nitrate reduction ${ }^{\star}$ & + & + & $+1-\dagger$ & + & + & + \\
\hline Urease $^{\star}$ & - & $+1-\dagger$ & - & $+1-\dagger$ & - & - \\
\hline \multicolumn{7}{|l|}{ Acid production from: } \\
\hline D-Galactose & - & - & - & + & - & - \\
\hline D-Glucose & - & + & - & + & + & + \\
\hline D-Fructose & + & - & - & + & + & + \\
\hline Glycerol & - & - & - & + & + & + \\
\hline Maltose & - & - & - & + & + & + \\
\hline D-Mannitol & + & ND & - & + & - & - \\
\hline Sucrose & + & - & - & + & - & - \\
\hline Major fatty acids & $\begin{array}{r}\text { ai- } C_{15: 0}, i-C_{15: 0}, \\
\text { i- } C_{16: 0}, i-C_{17: 0}\end{array}$ & $\begin{array}{l}\text { ai- } C_{15: 0}, \mathrm{i}-\mathrm{C}_{15} \\
\mathrm{i}-\mathrm{C}_{16: 0}, \text { ai- } \mathrm{C}_{1}\end{array}$ & $\begin{array}{l}\text { ai- } C_{15: 0}, i-C_{15: 0} \\
\text { ai- } C_{17: 0}, i-C_{16: 0}\end{array}$ & $\begin{array}{c}\mathrm{i}-\mathrm{C}_{15: 0}, \text { ai- } \mathrm{C}_{15: 0}, \\
\mathrm{C}_{16: 0}, \mathrm{i}-\mathrm{C}_{16: 0}\end{array}$ & $\begin{array}{r}\text { ai- } C_{15: 0}, i-C_{15: 0} \\
C_{16: 0}, \text { ai- } C_{17: 0}\end{array}$ & $\begin{array}{c}\text { ai- } \mathrm{C}_{15: 0}, \mathrm{i}- \\
\mathrm{C}_{15: 0}, \mathrm{i}-\mathrm{C}_{17: 0} \\
\text { ai- } \mathrm{C}_{17: 0}\end{array}$ \\
\hline
\end{tabular}

${ }^{\star}$ Unless otherwise indicated, results of these tests for S. alkaliphilus JCM $11311^{\mathrm{T}}$, S. roseus DSM $5351^{\mathrm{T}}$ and S. hispanicus DSM $5352^{\mathrm{T}}$ were confirmed in parallel tests with strain YIM Y $15^{\mathrm{T}}$ under identical conditions. The Voges-Proskauer test was negative for all four strains in the parallel test. $\dagger$ Results from this study. 
composition was determined as described by Sasser (1990) using the Microbial Identification System (MIDI; Microbial ID) with cells grown on MA supplemented with $8 \%(\mathrm{w} / \mathrm{v}) \mathrm{NaCl}$ for 3 days at $37{ }^{\circ} \mathrm{C}$. DNA was isolated according to Hopwood et al. (1985) and its G + C content was determined by the thermal denaturation method (Mandel \& Marmur, 1968) with a Shimadzu UV-visible spectrophotometer (UV1601).

Chemotaxonomic data for strain YIM Y $15^{\mathrm{T}}$ are compatible with its assignment to the genus Salinicoccus. The major amino acid constituents of the cell-wall hydrolysate were glycine and lysine, which is compatible with the murein type of L-Lys-Gly ${ }_{5}$ described for the genus Salinicoccus (Ventosa et al., 1990). The strain studied had menaquinone 6 (MK-6) (98.8\%) and MK-7 (1.2\%) as its respiratory quinones. The fatty acid profiles of strain YIM $\mathrm{Y}^{2} 5^{\mathrm{T}}$ and related type strains are given in Table 2. The major fatty acids of the strain studied were iso- and anteiso-branched fatty acids [ai- $\mathrm{C}_{15: 0}(28.4 \%), \mathrm{i}-\mathrm{C}_{15: 0}(23.1 \%)$, ai- $\mathrm{C}_{17: 0}$ $(5.8 \%), \mathrm{i}-\mathrm{C}_{16: 0}(5.8 \%)$ and $\left.\mathrm{i}-\mathrm{C}_{17: 0}(5.7 \%)\right]$. The DNA $\mathrm{G}+\mathrm{C}$ content of strain YIM Y $15^{\mathrm{T}}$ was $46.2 \mathrm{~mol} \%$.

The yellow pigmentation and wide growth temperature range $\left(4-45{ }^{\circ} \mathrm{C}\right)$ of strain YIM Y15 $5^{\mathrm{T}}$, together with the presence of MK-7 (1.2\%) in minor amounts and some biochemical characteristics, such as the ability to hydrolyse aesculin and Tween 80 and acid production from Dfructose, D-mannitol and sucrose, differed markedly from the five described Salinicoccus species (Table 1).

On the basis of the phylogenetic, chemotaxonomic and phenotypic results presented above, we propose that strain YIM $\mathrm{Y}^{\mathrm{T}}{ }^{\mathrm{T}}$ represents a novel species of the genus Salinicoccus, Salinicoccus kunmingensis sp. nov.

\section{Description of Salinicoccus kunmingensis sp. nov.}

Salinicoccus kunmingensis (kun.ming.en'sis. N.L. masc. adj. kunmingensis pertaining to Kunming, a city in south-west China, near which the sample from which the type strain was isolated was collected).

Cells are Gram-positive, non-motile, non-sporulating, catalase- and oxidase-positive, obligately aerobic cocci $(0.8-1.2 \mu \mathrm{m})$ that occur singly or in pairs, tetrads or clumps. Colonies are circular, convex, yellow-pigmented and non-translucent with shiny, glistening surfaces and entire margins, $2-3 \mathrm{~mm}$ in diameter after 3 days on MA supplemented with $8 \%(\mathrm{w} / \mathrm{v}) \mathrm{NaCl}$ at $\mathrm{pH} 8.0$ and $37{ }^{\circ} \mathrm{C}$. No diffusible pigments are produced on any media tested. Growth occurs at $4-45{ }^{\circ} \mathrm{C}$ (optimum $37^{\circ} \mathrm{C}$ ) and $\mathrm{pH} 6.0$ 10.0 (optimum $\mathrm{pH}$ 8.0). Moderately halophilic, with growth at $0.5-25 \%(\mathrm{w} / \mathrm{v}) \mathrm{NaCl}$ [optimum $8-10 \%(\mathrm{w} / \mathrm{v})$ $\mathrm{NaCl}$. Also grows well on MA supplemented with 2-15\% (w/v) $\mathrm{MgCl}_{2}$ or $\mathrm{KCl}$ instead of $\mathrm{NaCl}$. Positive for hydrolysis of aesculin, starch and Tween 80, but negative for hydrolysis of casein, chitin, gelatin and Tween 20. Nitrate is reduced to nitrite. Voges-Proskauer and methyl red tests
Table 2. Fatty acid composition of strain $\mathrm{YIM} Y 15^{\top}$ and members of the genus Salinicoccus

Strains: 1, YIM Y $15^{\mathrm{T}}$ (data from this study); 2, S. alkaliphilus JCM $11311^{\mathrm{T}}$ (data from Zhang et al., 2002); 3, S. roseus DSM $5351^{\mathrm{T}} ; 4$, S. hispanicus DSM $5352^{\mathrm{T}}$ (data in columns 3 and 4 from Yoon et al., 2003); 5, S. jeotgali KCTC $13030^{\mathrm{T}}$ (Aslam et al., 2007); 6, S. salsiraiae LMG $22840^{\mathrm{T}}$ (França et al., 2006). Values are percentages of total fatty acids. -, Not detected; ND, no data. Other components in the fatty acid pool of strain YIM Y15 $5^{\mathrm{T}}(\%)$ are iso- $\mathrm{C}_{15: 1}$ at $5(0.9)$, iso- $\mathrm{C}_{15: 1} \mathrm{I}$ (0.5), anteiso- $\mathrm{C}_{15: 1} \mathrm{~A}(0.3), \mathrm{C}_{17: 0}(0.2)$ and iso- $\mathrm{C}_{17: 1} \mathrm{I}(0.6)$.

\begin{tabular}{|c|c|c|c|c|c|c|}
\hline Fatty acid & 1 & 2 & 3 & 4 & 5 & 6 \\
\hline \multicolumn{7}{|l|}{ Saturated fatty acids } \\
\hline $\mathrm{C}_{14: 0}$ & 1.9 & 1.6 & - & 0.5 & 4.4 & $0.8 \pm 0.2$ \\
\hline $\mathrm{C}_{15: 0}$ & 0.7 & - & 0.7 & 0.5 & - & - \\
\hline $\mathrm{C}_{16: 0}$ & 3.2 & 1.5 & 1.0 & 2.7 & 10.3 & $2.9 \pm 0.4$ \\
\hline $\mathrm{C}_{17: 0} 3-\mathrm{OH}$ & - & - & 0.5 & - & - & ND \\
\hline $\mathrm{C}_{18: 0}$ & 2.1 & - & - & 1.5 & - & $0.7 \pm 0.1$ \\
\hline $\mathrm{C}_{20: 0}$ & 0.2 & 1.3 & - & - & - & $2.1 \pm 0.5$ \\
\hline \multicolumn{7}{|l|}{$\begin{array}{l}\text { Unsaturated fatty } \\
\text { acids }\end{array}$} \\
\hline $\mathrm{C}_{16: 1} \omega 7 c$ alcohol & 3.4 & 5.8 & 0.6 & 0.8 & 4.1 & - \\
\hline $\mathrm{C}_{16: 1} \omega 11 c$ & 2.7 & 2.2 & - & - & 3.6 & - \\
\hline $\mathrm{C}_{18: 1} \omega 5 c$ & - & - & 0.7 & - & - & ND \\
\hline $\mathrm{C}_{18: 1} \omega 7 c$ & 0.4 & - & - & 0.7 & - & ND \\
\hline $\mathrm{C}_{18: 1} \omega 9 c$ & 0.5 & - & - & 0.5 & - & ND \\
\hline \multicolumn{7}{|l|}{ Branched fatty acids } \\
\hline iso- $\mathrm{C}_{13: 0} 3-\mathrm{OH}$ & 1.0 & - & - & - & - & $\mathrm{ND}$ \\
\hline iso- $\mathrm{C}_{14: 0}$ & 2.9 & 4.4 & 0.6 & 0.5 & 3.2 & $1.0 \pm 0.1$ \\
\hline iso- $\mathrm{C}_{15: 0}$ & 23.1 & 22.3 & 12.5 & 20.8 & 22.8 & $26.6 \pm 2.2$ \\
\hline anteiso- $\mathrm{C}_{15: 0}$ & 28.4 & 27.6 & 32.9 & 35.9 & 32.4 & $35.3 \pm 0.7$ \\
\hline iso- $\mathrm{C}_{16: 0}$ & 5.8 & 10.1 & 4.3 & 2.5 & 4.1 & $3.5 \pm 0.6$ \\
\hline iso- $\mathrm{C}_{17: 0}$ & 5.7 & 3.3 & 6.2 & 8.8 & - & $9.5 \pm 0.8$ \\
\hline iso- $\mathrm{C}_{17: 1} \omega 10 c$ & 4.7 & 4.0 & 7.3 & 3.5 & - & $3 \pm 0.3$ \\
\hline iso- $\mathrm{C}_{17: 0} 3-\mathrm{OH}$ & - & - & 1.0 & - & - & $\mathrm{ND}$ \\
\hline anteiso- $\mathrm{C}_{17: 0}$ & 5.8 & 8.9 & 13.5 & 11.9 & 6.2 & $8.5 \pm 0.6$ \\
\hline iso- $\mathrm{C}_{18: 0}$ & 0.5 & - & 0.6 & - & - & ND \\
\hline iso- $\mathrm{C}_{19: 0}$ & 0.7 & 2.8 & 2.3 & 2.5 & - & $3.0 \pm 0.1$ \\
\hline anteiso- $\mathrm{C}_{19: 0}$ & 1.0 & 1.9 & 5.8 & 1.7 & - & $1.0 \pm 0.2$ \\
\hline iso- $\mathrm{C}_{20: 0}$ & - & 1.5 & - & - & - & - \\
\hline Summed feature $4^{*}$ & - & - & 0.8 & 0.6 & - & ND \\
\hline Unknown $\dagger$ & 2.8 & 0.9 & 1.4 & 1.2 & 4.3 & $2.3 \pm 0.3$ \\
\hline
\end{tabular}

${ }^{*}$ Summed feature 4 represents iso- $\mathrm{C}_{17: 1} \mathrm{I}$ and/or anteiso- $\mathrm{C}_{17: 1} \mathrm{~B}$, which could not be separated by GLC with the MIDI system.

$\dagger$ Unknown fatty acids with equivalent chain-lengths of 15.665 for $S$. alkaliphilus JCM $11311^{\mathrm{T}}, 15.669$ for strain YIM Y15 ${ }^{\mathrm{T}}$, S. roseus DSM $5351^{\mathrm{T}}$, S. hispanicus DSM $5352^{\mathrm{T}}$ and S. jeotgali KCTC $13030^{\mathrm{T}}$ and 15.670 for S. salsiraiae LMG $22840^{\mathrm{T}}$.

are negative. $\mathrm{H}_{2} \mathrm{~S}$ and indole are not produced. Cells are resistant to gentamicin $(10 \mu \mathrm{g})$, kanamycin $(30 \mu \mathrm{g})$, lincomycin $(2 \mu \mathrm{g})$, polymyxin B $(30 \mu \mathrm{g})$ and streptomycin $(10 \mu \mathrm{g})$, but ampicillin $(30 \mu \mathrm{g})$, chloramphenicol $(30 \mu \mathrm{g})$, nalidixic acid $(20 \mu \mathrm{g})$, novobiocin $(30 \mu \mathrm{g})$, rifampicin $(5 \mu \mathrm{g})$ and tetracycline $(30 \mu \mathrm{g})$ inhibit growth. In API 20NE strips, a positive result is obtained for assimilation of potassium gluconate and negative results are obtained for 
assimilation of glucose, arabinose, mannose, mannitol, $\mathrm{N}$ acetylglucosamine, maltose, capric acid, adipic acid, malate, trisodium citrate and phenylacetic acid and fermentation of glucose. Acid is produced from amygdalin, $\mathrm{N}$-acetylglucosamine, D-fructose, inositol, D-lactose, Dmannitol and sucrose in API 50CH strips. In Biolog GP2 plates, the following substrates are used as sole carbon and energy sources: $N$-acetyl-D-glucosamine, amygdalin, Larabinose, D-cellobiose, D-fructose, D-glucose, glycerol, $\gamma$ hydroxybutyric acid, myo-inositol, $\alpha$-D-lactose, D-mannitol, D-mannose, D-psicose, D-raffinose, L-rhamnose, D-ribose, sucrose, trehalose, Tween 40, L-alaninamide and Lasparagine. Constitutive enzymes expressed by the type strain are catalase, cytochrome oxidase, alkaline phosphatase, esterase (C4), esterase lipase (C8), lipase (C14), leucine arylamidase, cystine arylamidase, $\alpha$-chymotrypsin, $\alpha$-mannosidase, gelatinase, acid phosphatase, naphthol-ASBI-phosphohydrolase and valine arylamidase. Arginine dihydrolase, $\alpha$-galactosidase, $\beta$-galactosidase, $\alpha$-glucosidase, $\beta$-glucosidase, $\beta$-glucuronidase, trypsin, $N$-acetyl- $\beta$-glucosaminidase, $\beta$-galactosidase/o-nitrophenyl- $\beta$-D-galactopyranosidase (ONPG), tryptophan deaminase, lysine decarboxylase, $\beta$-galactosidase/ $p$-nitrophenyl- $\beta$-D-galactopyranosidase (PNPG), ornithine decarboxylase, $\alpha$-fucosidase and urease are not produced. The assumed cell-wall murein type is L-Lys-Gly. The predominant respiratory quinone is MK-6, and MK-7 is present in minor amounts. The major cellular fatty acids are anteiso- $\mathrm{C}_{15: 0}(28.4 \%)$ and iso- $\mathrm{C}_{15: 0}(23.1 \%)$. The DNA G $+\mathrm{C}$ content of the type strain is $46.2 \mathrm{~mol} \%$.

The type strain, YIM Y15 ${ }^{\mathrm{T}}\left(=\mathrm{DSM} 17847^{\mathrm{T}}=\right.$ CGMCC $1.6302^{\mathrm{T}}$ ), was isolated from a brine sample collected from the Yipinglang salt mine in Kunming, south-west China.

\section{Acknowledgements}

This work was supported by grants from the National Natural Science Foundation of China (NSFC) (30460004, 30660004, 30360004, 30560001 and 30260004), SRF for ROCS (SEM), the Yunnan Provincial Sciences and Technology Department (2005PY01-1, 2004C0002Z and 2006C0006M) and the National Basic Research Program of China (973 Program, no. 2004CB719601). We are grateful to Wen-Dong Zhang, Qin Zhou, Yu-Rong Yang and Li-Xia Duan for their excellent technical assistance. We are grateful to Dr Jean Euzéby for recommending the proper etymology.

\section{References}

Aslam, Z., Lim, J. H., Im, W.-T., Yasir, M., Chung, Y. R. \& Lee, S.-T. (2007). Salinicoccus jeotgali sp. nov., isolated from jeotgal, a traditional Korean fermented seafood. Int J Syst Evol Microbiol 57, 633-638.

Cowan, S. T. \& Steel, K. J. (1965). Manual for the Identification of Medical Bacteria. London: Cambridge University Press.

Cui, X.-L., Mao, P.-H., Zeng, M., Li, W.-J., Zhang, L.-P., Xu, L.-H. \& Jiang, C.-L. (2001). Streptomonospora salina gen. nov., sp. nov., a new member of the family Nocardiopsaceae. Int J Syst Evol Microbiol 51, 357-363.
Dombrowski, H. J. (1966). Geological problems in the question of living bacteria in Paleozoic salt deposits. In Second Symposium on Salt, vol. I, pp. 215-219. Edited by J. L. Rau. Cleveland, OH: Northern Ohio Geological Society.

Felsenstein, J. (1981). Evolutionary trees from DNA sequences: a maximum likelihood approach. J Mol Evol 17, 368-376.

Felsenstein, J. (1985). Confidence limits on phylogenies: an approach using the bootstrap. Evolution 39, 783-791.

Felsenstein, J. (1993). PHYLIP (phylogeny inference package), version 3.5. Distributed by the author. Department of Genome Sciences, University of Washington, Seattle, USA.

França, L., Rainey, F. A., Nobre, M. F. \& Da Costa, M. S. (2006). Salinicoccus salsiraiae sp. nov.: a new moderately halophilic grampositive bacterium isolated from salted skate. Extremophiles 10, 531-536.

Gerhardt, P., Murray, R. G. E., Costilow, R. N., Nester, E. W., Wood, W. A., Krieg, N. R. \& Philips, G. B. (editors) (1981). Manual of Methods for General Bacteriology. Washington, DC: American Society for Microbiology.

Grant, W. D., Gemmell, R. T. \& McGenity, T. J. (1998). Halobacteria the evidence for longevity. Extremophiles 2, 279-287.

Gregersen, T. (1978). Rapid method for distinction of Gram-negative from Gram-positive bacteria. Eur J Appl Microbiol Biotechnol 5, 123-127.

Groth, I., Schumann, P., Weiss, N., Martin, K. \& Rainey, F. A. (1996). Agrococcus jenensis gen. nov., sp. nov., a new genus of actinomycetes with diaminobutyric acid in the cell wall. Int J Syst Bacteriol 46, 234-239.

Hopwood, D. A., Bibb, M. J., Chater, K. F., Kieser, T., Bruton, C. J., Kieser, H. M., Lydiate, D. J., Smith, C. P. \& Ward, J. M. (1985). Preparation of chromosomal, plasmid and phage DNA. In Genetic Manipulation of Streptomyces: a Laboratory Manual, pp. 79-80. Norwich, UK: F. Crowe \& Sons.

Kimura, M. (1980). A simple method for estimating evolutionary rates of base substitutions through comparative studies of nucleotide sequences. J Mol Evol 16, 111-120.

Kluge, A. G. \& Farris, F. S. (1969). Quantitative phyletics and the evolution of anurans. Syst Zool 18, 1-32.

Kumar, S., Tamura, K., Jakobsen, I.-B. \& Nei, M. (2001). MEGA2: molecular evolutionary genetics analysis software. Bioinformatics $\mathbf{1 7}$, 1244-1245.

Kushner, D. J. (1993). Growth and nutrition of halophilic bacteria. In The Biology of Halophilic Bacteria, pp. 87-103. Edited by R. H. Vreeland \& L. I. Hochstein. Boca Raton, FL: CRC Press.

Mandel, M. \& Marmur, J. (1968). Use of ultraviolet absorbancetemperature profile for determining the guanine plus cytosine content of DNA. Methods Enzymol 12B, 195-206.

Marquez, M. C., Ventosa, A. \& Ruiz-Berraquero, F. (1990). Marinococcus hispanicus, a new species of moderately halophilic gram-positive cocci. Int J Syst Bacteriol 40, 165-169.

McGenity, T. J., Gemmell, R. T., Grant, W. D. \& Stan-Lotter, H. (2000). Origins of halophilic microorganisms in ancient salt deposits. Environ Microbiol 2, 243-250.

Norton, C. F. \& Grant, W. D. (1988). Survival of halobacteria within fluid inclusions in salt crystals. J Gen Microbiol 134, 1365-1373.

Norton, C. F., McGenity, T. J. \& Grant, W. D. (1993). Archaeal halophiles (halobacteria) from two British salt mines. J Gen Microbiol 139, 1077-1081.

Saitou, N. \& Nei, M. (1987). The neighbor-joining method: a new method for reconstructing phylogenetic trees. Mol Biol Evol 4, $406-425$. 
Sasser, M. (1990). Identification of bacteria by gas chromatography of cellular fatty acids. USFCC Newsl 20, 16.

Schleifer, K. H. (1985). Analysis of the chemical composition and primary structure of murein. Methods Microbiol 18, 123-156.

Shirling, E. B. \& Gottlieb, D. (1966). Methods for characterization of Streptomyces species. Int J Syst Bacteriol 16, 313-340.

Stackebrandt, E. \& Goebel, B. M. (1994). Taxonomic note: a place for DNA-DNA reassociation and $16 \mathrm{~S}$ rRNA sequence analysis in the present species definition in bacteriology. Int J Syst Bacteriol 44, 846-849.

Staneck, J. L. \& Roberts, G. D. (1974). Simplified approach to identification of aerobic actinomycetes by thin-layer chromatography. Appl Microbiol 28, 226-231.

Thompson, J. D., Gibson, T. J., Plewniak, F., Jeanmougin, F. \& Higgins, D. G. (1997). The CLUSTAL_X windows interface: flexible strategies for multiple sequence alignment aided by quality analysis tools. Nucleic Acids Res 25, 4876-4882.

Ventosa, A., Quesada, E., Rodriguez-Valera, F., Ruiz-Berraquero, F. \& Ramos-Cormenzana, A. (1982). Numerical taxonomy of moderately halophilic Gram-negative rods. J Gen Microbiol 128, 1959-1968.
Ventosa, A., Marquez, M. C., Ruiz-Berraquero, F. \& Kocur, M. (1990). Salinicoccus roseus gen. nov., sp. nov., a new moderately halophilic gram-positive coccus. Syst Appl Microbiol 13, 29-33.

Ventosa, A., Marquez, M. C., Weiss, N. \& Tindall, B. J. (1992). Transfer of Marinococcus hispanicus to the genus Salinicoccus as Salinicoccus hispanicus comb. nov. Syst Appl Microbiol 15, 530-534.

Vreeland, R. H. \& Powers, D. W. (1999). Considerations for microbiological sampling of crystals from ancient salt formations. In Microbiology and Biogeochemistry of Hypersaline Environments, pp. 53-74. Edited by A. Oren. Boca Raton, FL: CRC Press.

Vreeland, R. H., Rosenzweig, W. D. \& Powers, D. W. (2000). Isolation of a 250 million-year-old halotolerant bacterium from a primary salt crystal. Nature 407, 897-900.

Yoon, J. H., Lee, K. C., Weiss, N., Kang, K. H. \& Park, Y. H. (2003). Jeotgalicoccus halotolerans gen. nov., sp. nov. and Jeotgalicoccus psychrophilus sp. nov., isolated from the traditional Korean fermented seafood jeotgal. Int J Syst Evol Microbiol 53, 595-602.

Zhang, W., Xue, Y., Ma, Y., Zhou, P., Ventosa, A. \& Grant, W. D. (2002). Salinicoccus alkaliphilus sp. nov., a novel alkaliphile and moderate halophile from Baer Soda Lake in Inner Mongolia Autonomous Region, China. Int J Syst Evol Microbiol 52, 789-793. 